\title{
PERSPECTIVES AUDIOVISUALS DE L'ESPAI A LLUCIÀ DE SAMÒSATA
}

\author{
DAVID SOLÉ GIMENO \\ Universitat de Barcelona \\ dsoleg@ub.edu
}

ORCID: 0000-0002-0184-0664

RESUM

En un context en què els estudis sobre la percepció sensorial en l'Antiguitat són tendència, aquest article es proposa analitzar i demostrar com els sentits de la vista i l'oïda juguen un paper determinant en la construcció imaginària de l'espai a Llucià de Samòsata.

Si diverses evocacions sensorials activen una vívida ficció a Relats verídics (el receptor de la narració n'experimenta amb molta enárgeia les circumstantiae espacials), una sèrie de reflexions de caràcter audiovisual reprodueixen l'espai (circumstantia que, aquí, esdevé temàtica principal) descrit a Sobre la sala. Efectivament, l'autor insisteix en una sèrie d'evocacions visuals i auditives que promourien la imaginació d'un autèntic espai de declamació i performance fins al punt que arribarem a considerar aquesta laliá com una metàfora il-lustrativa de les bones pràctiques d'un sofista.

Comprovarem, doncs, com l'autor de Samòsata tenia una tendència habitual a recórrer als sentits de la percepció per captar l'atenció de l'auditori, implicar-lo en el context de les seves composicions i fer que imaginés vivament les situacions i els espais descrits.

PARAULES CLAU: Llucià de Samòsata, percepció sensorial, ékphrasis, enárgeia, narrativa, laliá.

\section{AUDIOVISUAL PERSPECTIVES OF SPACE IN LUCIAN OF SAMOSATA}

\section{ABSTRACT}

Studies in sensorial perception of space in the Classical Antiquity are currently trendy. Thus, the aim of this paper is to analyze and demonstrate how the sight and the audition senses have a special role to build an imaginary space in Lucian of Samosata.

On the one hand, in True Stories we identify sensorial evocations activating a fiction as vivid, so the public would experiment the circumstantiae of the plot in his own mind: something that appears ironically hyper realistic. On the other hand, we find similar examples and, specially, more reflexive ones that reproduce the space in The Hall, in which the main subject is the topographic circumstantia of a declamation room that would be a metaphor of the good techniques, which a sophist executes in their discourses.

Hence, we will demonstrate how the Samosata's writer used to apply the sensorial perception to make the public more interested and immersed in the spaces of the plot, imagining it as vividly as Lucian describes them.

KEYWORDS: Lucian of Samosata, sensorial perception, ékphrasis, enárgeia, narrative, laliá. 


\section{LA PERCEPCIÓ SENSORIAL EN L'ANTIGUITAT, TENDÈNCIA ACTUAL}

Avui dia, diversos estudis analitzen com era l'espai físic que envoltava els antics i la manera com aquests el concebien a través dels seus cinc canals sensorials. En efecte, investigadors que es dediquen a fer recerca sobre aquesta matèria ${ }^{1}$ recorren a diferents fonts literàries de l'Antiguitat per a descriure com era el món grecoromà a ulls, oïda, pell, olfacte i gust dels seus coetanis.

Tanmateix, aquí no pretenem fer una exposició exhaustiva de l'status quo d'aquests estudis, sinó que ens centrarem a comentar com diferents evocacions literàries als sentits de la vista i l'oïda exerceixen un rol important per a construir - de manera imaginària - l'espai físic. ${ }^{2}$ Abordarem aquesta qüestió comentant dues obres de Llucià de Samòsata: parlarem breument sobre Relats verídics ${ }^{3}$ i, tot seguit, centrarem l'atenció en el discurs retòric de Sobre la sala. ${ }^{4}$

\section{CiRCVMSTANTIAE PARADOXAls A RELATS VERÍDicS}

En el recorregut argumental de $V H$, trobem diverses evocacions sensorials que fan palesa una vívida ficció. Gràcies a aquesta tendència, el receptor de l'obra hauria experimentat amb molta vivacitat els fets relatats $i$, sobretot, les circumstantiae

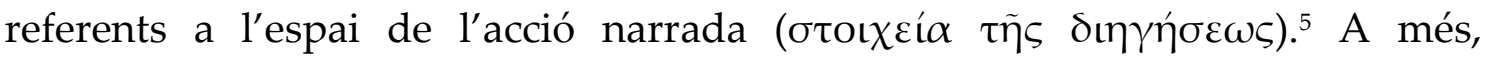
l'experiència directa del contingut del text hauria estat encara més efectiva gràcies a una performance, la veu i la gestualitat de la qual ${ }^{6}$ haurien posat de manifest l'enárgeia d'uns passatges evocadors als cinc sentits de la percepció. De fet, tals situacions constitueixen generalment casos d'ékphrasis (en el sentit més

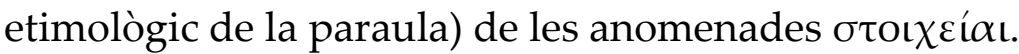

\subsection{Indrets ficticis però sensorialment hiperrealistes}

Així, si bé els escenaris de $V H$ són plenament irreals, paradoxalment, semblen hiperrealistes a la phantasía dels receptors a través de les referències sensorials que presenten. Amb això, ens trobem davant d'una evident provocació de Llucià, ja que vol fer penetrar el seu auditori ${ }^{7}$ en un món que, declaradament, és psê̂dos. ${ }^{8}$

${ }^{1}$ Cf. Butler i Purves (2013), Emerit et al. (2016), entre d'altres.

2 Per a una explicació retòrica i filosòfica de l'espai segons Aristòtil, $c f$. Corrales (2013).

${ }^{3} \mathrm{D}^{\prime}$ ara endavant, $V H$ (i.e. Verae Historiae).

${ }^{4}$ Designat com a Dom. (i.e. De Domo). Les traduccions dels passatges que citem són pròpies.

5 Vid. Nic. Prog. 13.

${ }^{6}$ Segons Bueche (2008: 108), «Des cinq parties de l'art oratoire, la plus importante est l'actio (ou pronuntiatio), qui règle à la fois la gestuelle, les mimiques et la voix de l'orateur».

${ }^{7}$ Considerem plausible que $V H$ (o alguns dels seus passatges) fossin recitats davant d'un públic oient. De fet, Dionís (una prolaliá) hauria servit a tall d'introducció del segon llibre de VH, segons Bompaire (1958: 288).

${ }^{8}$ Vid. $V H 1,2$. 
En efecte, l'autor aconseguirà aquesta fita a través de la vivacitat que estimula les parts cerebrals relacionades amb la percepció sensorial de la pròpia realitat.

\subsubsection{Una mirada irònicament crítica}

Encara que Llucià deixi palès que no ha vist res del que explicarà en el decurs de l'obra, ${ }^{9}$ la insistència en evocacions visuals durant tota l'aventura és evident. Aquest fenomen paradoxal demostra dos fets: d'una banda, es fa un blasme a la mala praxi de l'autopsía que, encabida sovint en ekphráseis, era conreada per part d'alguns historiadors; ${ }^{10}$ i, d'altra banda, la insistència en accions que impliquen la vista per tal d'afirmar que el protagonista és testimoni de les situacions més inversemblants representa una hipèrbole irònica que encaixa amb el perfil provocador de Llucià. ${ }^{11}$

\subsubsection{Ressons plàstics}

Diversos recursos sonors (al-literacions, harmonies imitatives i un cert ritme prosaic) ${ }^{12}$ apareixen en moments on el mateix text parla de situacions que perceben auditivament els personatges narratius (i, conseqüentment, el públic oient). ${ }^{13}$ Trobem ja precedents d'aquesta tendència en la tradició èpica, la qual recreà escenes de combat realment sorolloses, ${ }^{14}$ un koinós tópos que Llucià també hauria posat en pràctica.

Així doncs, aquests recursos «audiovisuals» (i també de la resta de sentits de la percepció $)^{15}$ haurien promogut una vívida representació imaginària de les circumstantiae locatives de la narració.

\footnotetext{
${ }^{9}$ Vid. ibid. 1, 4.

${ }^{10}$ Els quals les utilitzaven com una digressió i desmesuradament, segons el propi Llucià. De fet, l'ékphrasis «has tended to make people nervous» (Fowler 1991: 26); gent com el nostre autor a Com cal escriure la història (vid. Luc. Hist. conscr. 20).

${ }^{11}$ Cf. Saïd (1994).

${ }^{12}$ La plausibilitat del ritme d'alguns côla és evident a simple oïda a partir d'una emfàtica lectura oral.

13 Podem escoltar el ressò del ventre de la balena (Luc. VH. 1, 38), el bramar d'uns ases (ibid. 1, 17) o la remor llunyana d'un banquet (ibid. 2, 5).

14 Com els combats cos a cos entre troians i aqueus: $c f$. Braghin 2016: 75-80.

15 Trobem situacions en què els protagonistes perceben una sèrie d'olors, com el fort contrast entre l'aura asfixiant de l'Illa dels Benaurats (Luc. VH. 2, 5) i la desagradable fetor de l'illa dels condemnats a suplicis eterns (ibid. 2, 29); l'omnipresència de les corrents ventoses que acaricien totes les superfícies de l'espai narratiu (ibid. 1, 6; 2, 37, etc.) o escenes sexuals (ibid. 1, 8; 2, 45, etc.), que activarien el tacte; i, finalment, peixos amb gust de vi (ibid. 1, 7) o illes de formatge (ibid. 2, 3) que suposarien evocacions gustatives.
} 


\section{SOBRE LA SALA O LA MONOGRAFIA D'UN ESPAI RETÒRIC}

Dom. és una ékphrasis d'una sala erigida ad hoc per a pronunciar discursos retòrics. A diferència del context narratiu al qual acabem de referir-nos, a Dom. la descripció de la circumstantia espacial no és complementària al fil argumental, sinó que constitueix la temàtica principal del text. En efecte, tota la laliá se centra a fer circumloquis sobre la idoneïtat de l'indret on es parla. Aquest elogi conté sobretot una sèrie de reflexions basades en el paper dels sentits visual i auditiu que, indirectament, reprodueixen l'espai en la phantasía del públic. En general, l'admiració que provoca la bellesa de l'indret és l'element a partir del qual es teixeix la descripció al llarg de la laliá i, a diferència de $V H$, les referències «audiovisuals» voldrien reproduir, de facto, l'espai «real» del qual es parla i a l'interior del qual es parla per tal d'incitar el públic a fer-hi declamacions.

\subsection{Reflexions audiovisuals en un context de performance}

Al començament de l'obra, Llucià provoca els seus oients tot reflexionant sobre la necessitat de no quedar-se en silenci davant d'un bell espectacle que s'està contemplant. Així, en aquest context (Dom. 2), censura els ignorants conformistes

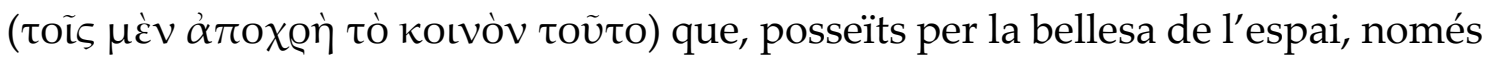

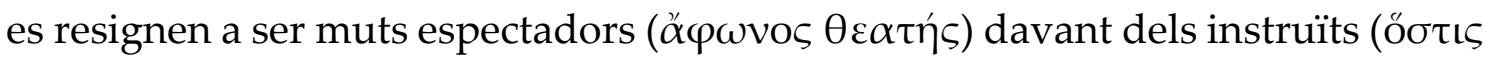
$\delta \dot{\varepsilon} \mu \varepsilon \tau \dot{\alpha} \pi \alpha ı \delta \varepsilon \dot{\alpha} \alpha \varsigma)$, els quals tractarien de respondre a l'espectacle a través del seu discurs, ja que la sensació d'admiració profunda provocada els interpel·laria de manera efectiva a fer-ho. De fet, aquesta contraposició ja queda ben palesa a Dom. 1, on Llucià contrasta l'actitud d'una persona culta i refinada ('A $\lambda \dot{\varepsilon} \xi \alpha v \delta \varrho o \varsigma)$ en un locus amoenus prototípic ${ }^{16}$ amb la d'algú qualsevol ( $\left.\tau \iota \varsigma\right)$ davant d'una idònia sala de conferències: ${ }^{17}$ el primer aprofitaria l'indret ocupant-lo físicament (banyant-se al riu) i el segon no ho faria (deixant-lo buit de paraules). Sigui com sigui, la resposta a l'espectacle contemplat hauria de consistir no només en un

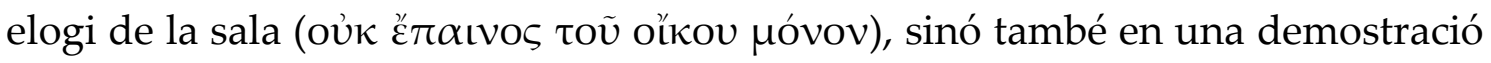

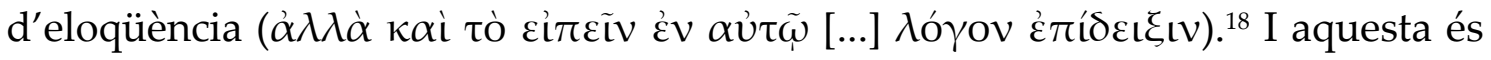
una declaració d'intencions, ja que la sala de conferències serà omplerta amb les seves paraules en el decurs de la laliá; l'autor donarà tanta importància a aquest fet que fins i tot el ressò del propi discurs, personificat, prendrà tot el protagonisme i seguirà fent reflexions diverses sobre $l^{\prime}$ «audiovisualitat» (és a dir, en definitiva, la idoneïtat) de la sala.

De fet, si ens fixem en l'estructura discursiva, podem dividir la laliá en dues parts, a propòsit de dues veus parlants diferents: d'una banda, l'elogi de la sala (Dom. 1-14) i, d'altra, el ressò del mateix discurs confirmant allò que s'ha dit a la

\footnotetext{
${ }^{16}$ El qual, de fet, recordaria a tantes altres situacions de la literatura grega com, per exemple, Sapph. P. Oxy. 2 o Pl. Phdr. 230 b.

17 Presentada, aquí, com un locus amoenus paral·lel a l'anterior.

18 Vid. Luc. Dom. 3.
} 
primera intervenció i que procura fer una demostració d'eloqüència al final de l'obra (Dom. 14-32). Aquesta estructura d' «acció-reacció» es correspondria amb les paraules pronunciades per l'orador i les d'agraïment del discurs, reverberades per l'eco de la pròpia sala.

\subsection{Aspectes visuals de la sala}

Durant la intervenció de la primera veu, es posa de relleu la bellesa de la disposició de la sala aportant informació sobre diversos fenòmens visuals: llums, colors i materials. Per exemple, es fa referència a l'harmonia de les seves proporcions i de la disposició dels seus elements estructurals o a la llum que hi entra, que és semblant a la que penetra en els temples. ${ }^{19} \mathrm{D}^{\prime}$ altra banda, explica la barreja de colors que esclaten com un llamp en entrar en contacte amb la llum, tot creant, així, una imatge realment espectacular. ${ }^{20} \mathrm{I}$, a més, els elements principals que composen la sala es comparen a la perfecció que caracteritza la pròpia primavera, ja que representen l'estació més plaent d'una manera perenne en contrast amb la real (efímera), fet que estableix una dicotomia freqüent a Llucià entre ficció i realitat. ${ }^{21}$

L'ús d'elements de la natura és novament recurrent per a evocar la visió de la sala i remarcar la seva funcionalitat: l'autor exposa com de plaent és córrer en una bella plana per a un cavall o passejar a través d'un prat per a un paó, ja que és aquí on aquests animals fan gala de la seva ufanosa bellesa. ${ }^{22}$ De la mateixa manera que en aquests loci amoeni els animals demostren les seves millors destreses o atributs (el cavall, la cursa; i el paó, la seva cua acolorida), es pot llegir entre línies com s'incita al fet que un deixeble de la paideía demostri també les seves grans habilitats en un espai tan íavós com és aquesta sala. És a dir, es tracta que, inspirat per la paideía, l'orador admiri l'espai i aprofiti l'avinentesa per a pronunciar-hi discursos ben construïts. Aquesta hipòtesi s'acaba confirmant a Dom. 13, on s'afirma que la sala pot causar el mateix efecte al sofista que una plana o un prat als animals que hem esmentat. ${ }^{23}$

\subsection{Aspectes auditius de la sala}

Llucià fa servir nombroses vegades el recurs de l'eco per tal d'il·lustrar la sonoritat de la sala, una reverberació recreada en una sèrie de símils. A Dom. 3, s'equipara el ressò amb el que hi ha a les coves, un element que podria recordar la mateixa sonoritat que Llucià diu que es reprodueix a l'interior de la balena de

19 Vid. ibid. 6.

${ }^{20} \mathrm{Vid}$. ibid. 8.

${ }^{21}$ Com hem vist, de fet, en el cas de $V H$ (vid. supra): una ficció que conté descripcions hiperrealistes de l'espai.

${ }^{22}$ Vid. Luc. Dom. 10-11.

23 «De la mateixa manera, la bellesa d'aquesta sala també és capaç d'incitar al discurs, de desvetllar l'orador i fer-lo triomfar en tots els sentits». 
$V H .{ }^{24}$ Tot seguit, en el mateix paràgraf del text, l'autor parla de la repetició de la veu pronunciada amb el ressò de les flautes dels pastors als cims de les muntanyes, una remor que recordaria la que s'escolta en un primer moment de l'arribada dels protagonistes de $V H$ a l'Illa dels Benaurats. ${ }^{25}$ De l'eco i l'òptima sonoritat de la casa, en tornarà a fer referència, també, més tard, a Dom. 16, quan parla sobre la potència de la veu: s'acaba intuint que el ressò que emet la sala, la «resposta» al discurs de l'orador (en definitiva, l'eco d'una deguda demostració d'eloqüència), acaba esvaint la veu primerament emesa.

Amb la descripció d'aquestes sonoritats, volem fer notar com Llucià evidencia un interès per implicar l'oient en l'espai i, alhora, convidar-lo a reproduir-hi discursos que l'elogiïn. Tenint això en compte, doncs, suposem que el públic al qual es dirigia l'autor devia estar format per aspirants a la paideía, els quals haurien posat en pràctica els seus exercicis retòrics in situ.

\subsection{Hegemonia visual sobre l'audició}

Ja a Dom. 4, comprovem com la visió de l'espai és una mena de Musa que

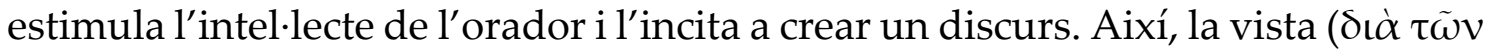
ò $\varphi \theta \alpha \lambda \mu \tilde{\omega} v)$ constitueix la font principal d'inspiració i es troba íntimament relacionada amb la veu del discurs, que omple l'espai. Amb aquesta reflexió, que recorda al procés d'inspiració pel qual el poeta és testimoni d'allò que les Muses li fan saber (és a dir, «veure») i, després, cantar, es palesa com la vista és un sentit superior (o «causant», «anterior») a l'oïda.

Si bé Llucià es refereix a la sonoritat de la sala, sempre tindrà un paper predominant l'aspecte visual. Tant és així que l'autor farà aparèixer en escena (Dom. 20) un autèntic argument d'autoritat perquè el recolzi en la seva tesi. Es tracta de l'historiador Heròdot, que, tenint en compte el fenomen de l'autopsía, dona molta més importància a tot allò vist que a allò escoltat, cosa que emfasitza la importància del paisatge visual de la sala. A més, tot seguit, Llucià recorda que els ع̌r $\pi \alpha \pi \tau \varepsilon \varrho o ́ \varepsilon v \tau \alpha$ són indiscutiblement efímers davant d'allò que pot ser contemplat de manera permanent, com la pròpia sala.

De fet, quan el discurs personificat es proposa fer l'ékphrasis de la sala (diu que va a fer-ho), ${ }^{26}$ ja l'ha duta a terme anteriorment a partir dels elogis i afirmant que qualsevol discurs que s'hi pogués pronunciar seria insignificant en comparació amb el que s'hi pot contemplar. Així, la visió guanya l'audició, essent aquesta darrera un mer complement. Tanmateix, abans d'iniciar el seguit d'ekphráseis dedicades als frescos murals de la sala, el discurs evoca una evident

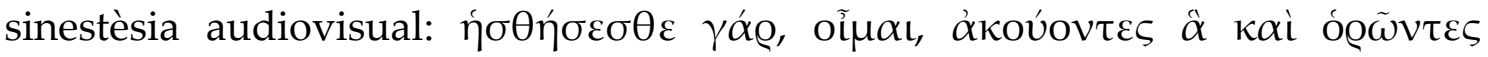
$\theta \alpha v \mu \alpha ́ \zeta \varepsilon \tau \varepsilon{ }^{27}$

\footnotetext{
${ }^{24}$ Vid. Luc. VH. 1, 38.

${ }^{25}$ Vid. ibid. $2,5$.

${ }^{26}$ Vid. Luc. Dom. 21: «[...] au!, us faré la millor descripció que pugui amb el meu discurs».

${ }^{27}$ Vid. ibid.: «Gaudireu, crec, escoltant les mateixes escenes que admireu en veure-les».
} 
Així doncs, quan pronuncia l'ékphrasis, es limita a fer-la de les obres d'art que hi ha a les parets i no pas d'una manera molt detallada. En conjunt, doncs,

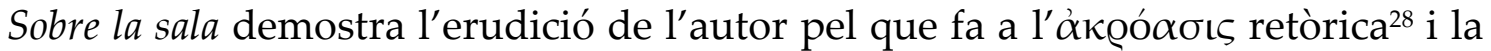
importància de la visió en el coneixement de la veritat, però no pas per la confecció d'una ékphrasis molt detallada. La contínua provocació de Llucià ens faria concloure que el més espectacular és imaginar-se a través de la phantasía els detalls que queden difosos no només dels frescos sinó també de la resta de la sala, que ha estat extremadament lloada $i$, en realitat, menys descrita del que es podia esperar. Així doncs, ens trobem davant d'una ékphrasis més reflexiva que descriptiva, però on l'expressió i l'eficàcia retòriques no deceben el públic receptor.

\section{LA SALA IDÒNIA: UN MODEL A SEGUIR}

A partir dels passatges que hem anat comentant, podem considerar que l'espai de Dom. constitueix una metàfora de les bones pràctiques d'un sofista a l'hora de compondre els seus discursos. En efecte, els atributs de la sala es podrien relacionar, a mode d'hipàl-lage, amb els atributs d'un bon orador. Veiem com, d'entre els elements visuals que hem apuntat, Llucià parla sobre la conveniència visual i material de la sala (Dom. 7): comentant la proporció equilibrada d'or que

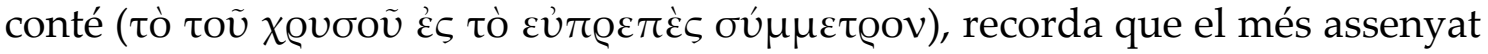
és mostrar una quantitat moderada d'elements decoratius i posa, com a exemple, el cas dels complements ornamentals que duen les dones belles. Tot seguit, contrasta aquest fet amb el cas de les prostitutes, especialment les més lletges, les quals s'empolainen exageradament d'or i porpra per a emmascarar la seva lletjor inevitable. Aquest paràgraf acaba amb un parell de períodes contraposats que demostren perfectament la preferència per una sala amb una quantitat

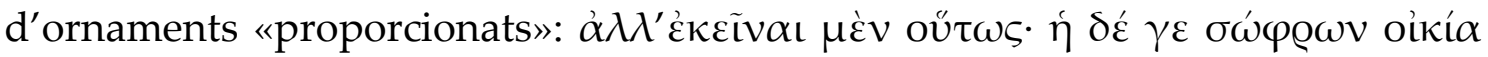

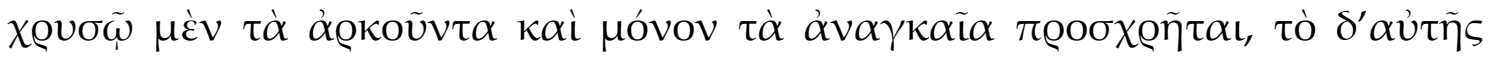

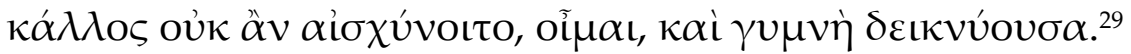

Així, si tenim en compte el paral·lelisme que hem interpretat, empolainar amb complements ornamentals un discurs que per se ja és de mala qualitat (és a dir, una prostituta lletja i, en definitiva, una sala no pas ben disposada) no serveix per a res. Efectivament, per a la confecció d'un bon discurs (és a dir, una dona bella o una sala digna d'elogis), sempre hi ha d'haver un bon rerefons, una bona «essència» que es pugui ornamentar amb un nombre equilibrat de complements per tal de fer-lo encara més agradable, no només aparent. Per tant, se'ns diu que la proporció d'or és convenient a la sala de la mateixa manera que una sèrie de

\footnotetext{
${ }^{28}$ D'aquesta pràctica retòrica en fa una bona descripció Berardi (2017: 41-44).

${ }^{29}$ «Elles [i.e. les prostitutes lletges] actuen d'aquesta manera. Tanmateix, una casa [i.e. la sala] assenyada utilitza l'or en la mesura convenient i necessària i no s'avergonyiria de la seva bellesa, crec, ni tan sols en mostrar-se nua».
} 
complements estètics acaben de fer més bonica una dona que, en principi, ja ho és. En canvi, una prostituta lletja (o sigui, interpretem, un «discurs insensat»), tot i que s'engalani amb joies i coloraines segueix sent, en el fons, una ampul-lositat buida de contingut. ${ }^{30}$ Finalment, tenint en compte que estem comparant un espai amb una dona, Llucià ratifica tot seguit la personificació de la sala mitjançant una metonímia de proximitat física, ja que considera el sostre de l'edifici com el seu

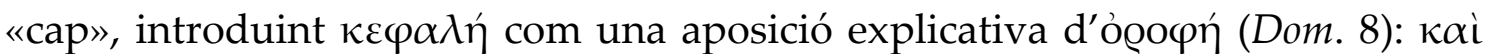

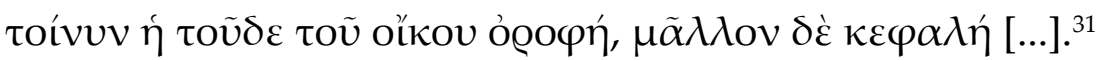

Així doncs, si equiparem la desmesura de complements ornamentals d'una dona lletja (o d'una sala) amb el nombre d'aticismes que potinegen encara més un mal discurs, ens trobaríem amb un cert paral-lelisme amb els consells que el protagonista del Mestre de Retòrica dona al seu deixeble per guanyar-se el favor de la Retòrica amb un resultat evidentment nefast. ${ }^{32}$

\section{EXPERIÈNCIES VÍVIDES D'ESPAIS DIFERENTS}

En aquestes dues obres de Llucià hem comprovat com l'autor presenta una evident tendència a recórrer als sentits de la vista i l'oïda a fi de captar l'atenció del públic, atrapar-lo en el context de les seves composicions i estimular una vívida imaginació que recrearia els espais narrats o descrits. Els uns, els de $V H$, són receptacles d'una paradoxal ficció literària i els altres, els de Dom., constitueixen el tema central del fil discursiu amb una finalitat metaliterària, de formació retòrica.

\section{BIBLIOGRAFIA}

BERARDI, F. (2017), La retorica degli esercizi preparatori. Glossario ragionato dei Progymnásmata, Hildesheim, Zuric i Nova York, OLMS.

BOMPAIRE, J. (1958), Lucien écrivain. Imitation et création, París, Bibliothèque des écoles françaises d'Athènes et de Rome.

BRAGHIN, A. (2016), «La vista e l'udito di Omero», a Nuda Veritas. Da Omero a Orson Welles, Camerotto, A. i Pontani, F. (eds.), Milà i Udine, Mimesis, 69-83.

BUECHE, S. (2008), «Vox, conditio sine qua non», a Langages et metaphores du corps dans le monde antique, Dasen, V. i Wilgaux, J. (eds.), Rennes, Presses universitaires de Rennes, 107-117.

Butler, S. i Purves, A. (2013), Synaesthesia and the Ancient Senses, Londres, Routledge.

\footnotetext{
${ }^{30}$ La contraposició entre la dona bella i la prostituta lletja ens faria pensar en l'ampul·lositat característica del moviment asianista davant la sobrietat i la concisió de la corrent aticista, del qual Llucià fou un dels grans exponents.

31 «De la mateixa manera, el sostre d'aquesta sala o, millor dit, el seu cap [...]».

32 Vid. Luc. Rh. Pr. 16.
} 
CORRALES, D. (2013), «Espacio, tiempo físico y lugares retóricos en Aristóteles», a Ouranós-Gaia. L'espai a Grècia III: anomenar l'espai, Jufresa, M. et al. (eds.), Tarragona, ICAC, 51-57.

EMERIT, S., PERROT, S. i VinCENT, A. (2015), Le paysage sonore de l'Antiquité. Méthodologie, historiographie et perspectives, El Caire, Institut Français d'Archéologie Orientale du Caire.

FOWLER, D. P. (1991), «Narrate and Describe: The Problem of Ekphrasis», The Journal of Roman Studies, 81, 25-35.

SAÏD, S. (1994), «Lucien ethnographe», a Lucien de Samosate: actes du colloque international de Lyon organisé au Centre d'Études Romaines et Galloromaines, le 30 septembre - 1er octobre 1993, Billault, A. (ed.), París, Centre d'études romaines et gallo-romaines, 149-170. 
